DOI https://doi.org/10.32837/app.v63i0.22

УДК 343.98

Виноградов В. I.* (НУ»ОЮА»)

\title{
ПЛАНУВАННЯ РОЗСЛІДУВАННЯ ЗЛОЧИНІВ У СФЕРІ ПУБЛІЧНИХ ЗАКУПІВЕЛЬ
}

\section{PLANNING OF CRIME INVESTIGATION IN PUBLIC PROCUREMENTS}

*Vadum Vynohradov - PhD Student (Law) of Department of Criminalistics, National university "Odessa law academy" (23, Fontanska Doroha St., Odesa, Ukraine).

\section{Abstract}

The article deals with the problems of planning the investigation of crimes in the field of public procurement. It is noted that the process of investigating public procurement crimes depends on the investigator's actions aimed at quickly and effectively clarifying the circumstances of the criminal event. The study used a method of transition from general to individual to objectively and comprehensively fulfill the purpose of the article. The notion of crime investigation planning in the general sense is defined, and the concept of crime investigation in the general sense in the field of public procurement is investigated in a broad sense through the prism of the characteristics of elements of crime investigation planning. Each of the elements of crime investigation planning is described and a classification of crime investigation planning elements in the field of public procurement by nature of the investigator's activity is given; by using additional resources; by the nature of the planning. The author's own vision of the concept and characteristics of elements of the planning of the investigation of crimes in the field of public procurement is offered.

Keywords: public procurement, public procurement crime, public procurement crime investigation, planning of crime investigation, planning of crime investigation in public procurements.

Постановка проблеми. Дієва антикорупційна політика держави, мінімізація корупційних ризиків є ознаками сучасної розвинутої держави, оскільки прояви корупції негативно впливають на формування стабільної економічної системи, іміджу держави на міжнародному 
рівні, а також на рівень довіри громадян. Напевно, наймасштабнішим «полем» проявів корупції по праву вважається сфера публічних закупівель. Проведення закупівель товарів, робіт і послуг, попри намагання змінити ситуацію, досі залишається криміналізованим та корумпованим процесом. При цьому, більшість злочинів у цій сфері має латентний характер (Коряк, 2012, с. 8).

Аналіз останніх досліджень та публікацій. Питання організації планування розслідування неодноразово підіймалося у працях Р. С. Бєлкіна, О. М. Васильєва, О. П. Ващук, В. Г. Гончаренка, В. В. Тіщенка, В. Ю. Шепітька. Якщо ж брати до уваги проблематику планування розслідування у сфері публічних закупівель, то ії розглядали такі дослідники, як: Ю. С. Доліновський, Д. В. Лазарева, А. М. Меденцев, А. Ю. Спусканюк.

Метою статті $є$ визначення характерних рис планування розслідування злочинів у сфері публічних закупівель та елементів планування розслідування.

Виклад основного матеріалу. Процес розслідування злочинів у сфері публічних закупівель напряму залежить від дій слідчого, направлених на швидке та ефективне з'ясування обставин кримінально-релевантної події. Як і кожен складний процес, розслідування злочинів потребує чіткої організації та складання власного алгоритму дій. Для кожної кримінально-релевантної події обирається методика розслідування, яка має привести до вирішення завдання кримінального провадження, передбаченого ст. 2 Кримінального процесуального кодексу України.

В. В. Тіщенко зазначає, що важливим принципом обрання та побудови методики розслідування будь-якого злочину є «планомірність ходу розслідування», тобто «використання планування для здійснення всіх процесуальних, слідчих (розшукових) та організаційних дій в певній послідовності» (Тіщенко, 2017, с. 33).

Планування розслідування, на думку М. А. Погорецького, є діяльністю слідчого, «яка полягає у визначенні оптимального переліку слідчих (розшукових) та інших процесуальних дій, строків і послідовності їх проведення з метою швидкого та ефективного розслідування конкретного злочину» (Погорецький, 2017, с. 43).

А. В. Іщенко вважає, що «планування тісно пов'язане з організацією розслідування в конкретному кримінальному провадженні, під яким розуміють комплекс заходів для створення оптимальних умов його реалізації. Якщо сутність планування полягає в тому, щоб 
вірно окреслити програму дій під час досудового розслідування, організація розслідування полягає в забезпеченні реалізації наміченого плану. Планування та організація органічно зв' язані, оскільки перше передбачає здійснення другого» (Іщенко, 2015, с. 318).

В. Г. Гончаренко (із співавторами) визначають планування розслідування як «процес встановлення шляхів, способів, засобів, сил і термінів успішного досягнення поставленої перед слідством мети під час розслідування конкретної кримінальної справи» (Варфоломєєва, Гончаренко В., Бояров, Гончаренко С., Попелюшко, 2011, c. 261).

Р. С. Бєлкін під технікою планування розслідування злочинів розуміє зовнішній (матеріальний) вираз уявного плану дій слідчого, тобто матеріалізацію його тактичного задуму, що визначає характер і черговість проведення слідчих (розшукових) дій і організаційнотехнічних заходів, взаємодію з фахівцями, оперативними працівниками, представниками громадськості (Белкин, 2001, с. 285).

Якщо ж взяти до уваги саме проблематику розслідування злочинів у сфері публічних закупівель, то слід звернутися до праць дослідників, зосереджених на зазначеному питанні. Ю. С. Доліновський, розглядаючи проблему розслідування злочинів під час публічних закупівель у сфері охорони здоров'я, визнаає, що «планування розслідування злочинів, які вчиняються під час публічних закупівель..., $\epsilon$ розумовою діяльністю слідчого, спрямованою на оцінку інформації про злочин, висунення версій, визначення на їхній основі обставин, що підлягають встановленню, і необхідних для цього слідчих (розшукових) дій та негласних слідчих (розшукових) дій із використанням допомоги оперативних підрозділів, експертів та інших спеціалістів» (Доліновський, Гула, 2018, с. 115).

Має місце і визначення планування розслідування злочинів у сфері публічних закупівель через характеристику його елементів. Такої позиції дотримується А. М. Меденцев (Меденцев, 2015, с. 116-117; Доліновський, 2017, с. 226-227).

Слідуючи від загального до окремого, варто визначити елементи планування розслідування у сфері публічних закупівель. Загальновизнаними елементами є аналітична обробка первинної інформації про подію; висунення версій та постановка завдань розслідування; визначення способів вирішення завдань розслідування; можливі корегування плану розслідування з огляду на обставини кримінального провадження. 
Під час аналітичної обробки первинної інформації про кримінально-релевантну подію перед слідчим постає необхідність виявити та оцінити усю наявну інформацію, як кримінально-правову (вид злочину, склад злочину), так і процесуальну (наприклад, ознайомитися із даними, внесеними до СРДР). На наступному етапі слідчому необхідно побудувати декілька версій того, що відбулося. Після цього важливо визначити, яке коло обставин не встановлено та підлягає встановленню в процесі розслідування злочинів у сфері публічних закупівель, які слідчі (розшукові) дії та негласні слідчі (розшукові) дії необхідно провести першочергово, а які після отримання результатів попередніх. Особливе значення для планування має визначення чіткої послідовності слідчих (розшукових) дій, які слідчий вважає за потрібне застосувати, та їх виконавців, але цей елемент має більш організаційний характер.

Постановка завдань розслідування злочинів у сфері публічних закупівель має передбачати розподіл завдань на первинні (першочергові) та вторинні. Серед першої категорії слід назвати встановлення осіб, причетних для виявлених правопорушень, застосування заходів забезпечення для збереження документації закупівель, тендерної документації, бухгалтерських та банківських документів, які можуть стосуватися розслідуваної події; визначити коло осіб, які можуть володіти інформацією про злочин. Друга категорія відзначається залученням державних органів та спеціалістів - експертних установ для проведення необхідних експертних досліджень; уповноважених органів для арешту банківських рахунків причетних до злочину структур, установ, осіб; спеціалістів для встановлення розміру завданої шкоди та збитків.

У випадках, коли розслідування злочину у сфері публічних закупівель потребує спеціальних знань, слідчий може використати допомогу спеціаліста або експерта, спеціаліста у сфері публічних закупівель. Результати такого звернення по допомогу спеціаліста випливають у власне корегування плану розслідування.

Як слушно зазначає А. М. Меденцев, організація розслідування злочинів у сфері публічних закупівель може вважатися створенням необхідних умов для успішного проведення запланованих слідчорозшукових дій, оперативно-розшукових заходів та забезпечення ïx необхідними силами і засобами. На думку дослідника, найбільш суттєвим елементом організації розслідування розглядається 
взаємодія слідчого з оперативними підрозділами у світлі положень КПК України (Меденцев, 2015, с. 11).

Загалом, з огляду на вивчення елементів планування розслідування злочинів у сфері публічних закупівель, слід класифікувати ці елементи за наступними підставами:

- за характером діяльності: організаційно-тактичні та процесуальні;

- за використанням додаткових ресурсів: із залученням спеціалістів та державних органів і самостійні дії слідчого;

- за характером планування: деталізовані та загальні елементи.

Висновки. Таким чином, планування розслідування злочинів у сфері публічних закупівель є складним процесом, спрямованим на отримання, оцінку інформації про кримінально-релевантну подію, висунення версій, встановлення обставин злочину, який часто потребує залученням додаткових ресурсів та проведення слідчих (розшукових) дій для встановлення дійсності у кримінальному провадженні у злочинах в сфері публічних закупівель.

\section{תimepamypa:}

Варфоломєєва Т. В., Гончаренко В. Г., Бояров В. І., Гончаренко С. В., \& Попелюшко В. О. (2011). Криміналістика. Академічний курс. Київ: Юрінком Інтер.

Доліновський Ю. С. (2017). Основи планування розслідування злочинів, що вчиняються під час публічних закупівель у сфері охорони здоров'я. Порівняльно-Аналітичне Право, (1), 226-229.

Доліновський Ю., Гула Л. (2018). Організація планування розслідування злочинів, що вчиняються під час публічних закупівель у сфері охорони здоров'я. Вісник Національного Університету “Львівська Політехніка". Серія: Юридичні Науки, 889(17), 110-116.

Коряк В. В. (2012). Протидія хабарництву у сорері державних закупівель оперативними підрозділами МВС : автореф. дис. ... канд. юрид. наук.

Меденцев А. М. (2015). Розслідування злочинів, щуо вчиняються у сорері державних закупівель : дис... канд. юрид. наук: 12.00.09.

Меденцев А. М. (2015). Розслідування злочинів, щуо вчиняються у сорері державних закупівель: авторефр. дис... канд.. юрид. наук: 12.00.09.

Погорецький М. А., Сєргєєва Д. Б. (Eds.). (2017). Криміналістична тактика (2nd-ге вид. еd.). Київ: Алерта. 
Пясковській В. В., Чорноус Ю. М., Іщенко А. В., Алєксєєв О. О. (2015). Криміналістика. Київ: Центр учбової літератури.

Тіщенко В. В. (2017). Криміналістична методика розслідування: теоретичні, методологічні та наукознавчі засади. Криминалисть Первопечатный, (15), 26-37.

\section{References:}

Dolinovs`ky`j Yu. S. (2017). Osnovy` planuvannya rozsliduvannya zlochy`niv, shho vchy`nyayut`sya pid chas publichny`x zakupivel`u sferi oxorony zdorov'ya [Basics of planning investigations into crimes committed in public procurement]. Porivnyal no-Anality chne Pravo [Porivnyal'no-analitychne pravo], (1), 226-229. [in Ukrainian].

Dolinovs`ky`jYu., Gula L. (2018). Organizaciya planuvannya rozsliduvannya zlochy`niv, shho vchy`nyayut`sya pid chas publichny`x zakupivel`u sferi oxorony'zdorov'ya [Organisation of planning of investigations into crimes committed in public procurement in the health care field]. Visny ' $k$ Nacional nogo Universy 'tetu "L'vivs 'ka Politexnika". Seriya: Yury'dy'chni Nauky ' Bulletin of National University "Lviv Polytechnica”. Series: Law], 889(17), 110-116. [in Ukrainian].

Koryak V. V. (2012). Proty 'diya xabarny 'cztou u sferi derzhavny x zakupivel operaty 'vny 'my pidrozdilamy MVS : avtoref. dy's. ... kand. yury'd. nauk [Countering bribery in the field of public procurement by operational units of the Ministry of Internal Affairs: abstract of thesis]. [in Ukrainian].

Medencev A. M. (2015). Rozsliduvannya zlochy 'niv, sho vchy 'nyayut sya u sferi derzhavny 'x zakupivel' : dy's... kand. yury'd. nauk: 12.00 .09 [Investigation of crimes committed in the field of public procurement: diss. lawyer. Sciences: 12.00.09]. [in Ukrainian].

Medencev A. M. (2015). Rozsliduvannya zlochy'niv, shho vchy'nyayut'sya u sferi derzhavny x zakupivel': avtoref. dy '... kand.. yury'd. nauk: 12.00.09 [Investigation of crimes committed in the field of public procurement: author. diss ... Cand. Jur. Sciences: 12.00.09]. [in Ukrainian].

Pogorecz`ky`j M. A., Syergyeyeva D. B. (Eds.). (2017). Kry`minalisty`chna takty ka (2nd-ge vy`d. ed.) [Forensic tactics (2nd ed. Ed.)]. Ky`yiv: Alerta. [in Ukrainian].

Pyaskovs`kij V. V., Chornous Yu. M., Ishhenko A. V., Alyeksyeyev O. O. (2015). Kry`minalisty $k a$ [Criminalistics]. Ky`yiv: Centr uchbovoyi literatury`. [in Ukrainian]. 
Tishhenko V. V. (2017). Kry`minalisty`chna metody`ka rozsliduvannya: teorety`chni, metodologichni ta naukoznavchi zasady` [Criminalistic methodology of investigation: theoretical, methodological and scientific basis]. Kry`my`naly`sto Pervopechatnuij [Forensic Scientist], (15), 26-37. [in Ukrainian].

Varfolomyeyeva T. V., Goncharenko V. G., Boyarov V. I., Goncharenko S. V., Popelyushko V. O. (2011). Kry 'minalisty ka. Akademichny jkurs [Criminalistics. Academic course]. Ky yiv: Yurinkom Inter. [in Ukrainian].

\footnotetext{
Анотація

Виноградов В. І. Планування розслідування злочинів у сфері публічних закупівель. - Стаття.

У статті розглядаються проблеми планування розслідування злочинів у сфері державних закупівель. Зазначається, щзо процес розслідування злочинів державних закупівель залежить від дій слідчого, спрямованих на швидке та ефективне з'ясування обставин злочинної подіі. У дослідженні використано метод переходу від загального до індивідуального до об'єктивного та всебічного виконання мети статті. Визначено поняття планування розслідування злочинів у загальному розумінні, а концепція розслідування злочинів у загальному розумінні у сорері державних закупівель досліджується в широкому розумінні через призму характеристик елементів планування розслідування злочинів. Охарактеризовано кожен із елементів планування розслідування злочинів та подано класифікацію елементів планування розслідування злочинів у сфері державних закупівель за характером діяльності слідчого; використання додаткових ресурсів; за характером планування. Запропоновано власне бачення автора концепиї та характеристик елементів планування розслідування злочинів у сфері державних закупівель.

Ключові слова: державні закупівлі, злочини у сфері державних закупівель, розслідування злочинів у сфері державних закупівель, планування розслідування злочинів, планування розслідування злочинів у сфері державних закупівель.
} 